\title{
Correction to: Discontinuous precipitation of rutilated quartz: grain-boundary migration induced by changes to the equilibrium solubility of Ti in quartz
}

Jay B. Thomas ${ }^{1}$ (D) William O. Nachlas ${ }^{1}$

Published online: 18 April 2020

๑) Springer-Verlag GmbH Germany, part of Springer Nature 2020

\section{Correction to:}

Contributions to Mineralogy and Petrology (2020)

175:38

https://doi.org/10.1007/s00410-020-01676-2

The original version of this article contained a mistake. After submitting the author-corrected proofs, the words omphacite and diopside in a reaction in the second paragraph were misspelled during typesetting. The correct reaction is:

diopside + albite $=2$ omphacite + quartz .

This erratum corrects the mistake and the original article is updated.
Publisher's Note Springer Nature remains neutral with regard to jurisdictional claims in published maps and institutional affiliations.

The original article can be found online at https://doi.org/10.1007/ s00410-020-01676-2.

Jay B. Thomas

jthom102@syr.edu

1204 Heroy Geology Laboratory, Department of Earth

Sciences, Syracuse University, Syracuse, NY 13244, USA 